\title{
Endophytic Cryphonectriaceae on native Myrtales: possible origin of Chrysoporthe canker on plantation-grown Eucalyptus
}

\author{
${ }^{1}$ Mausse-Sitoe SND., ${ }^{2}$ Rodas C., ${ }^{1}$ Wingfield MJ., ${ }^{1,3}$ Chen SF., ${ }^{1}$ Roux J. \\ ${ }^{1}$ Department of Microbiology, Forestry and Agricultural Biotechnology Institute (FABI), University of \\ Pretoria, Private Bag X20, Hatfield, Pretoria, 0028, South Africa \\ ${ }^{2}$ Forestry Protection Programme, Smurfit Kappa Cartón de Colombia. Calle 15 \#18-109 Puerto Isaacs - \\ Yumbo, Valle, Colombia \\ ${ }^{3}$ China Eucalyptus Research Centre (CERC), Zhanjiang, Guangdong, China
}

Corresponding author: Jolanda.roux@ fabi.up.ac.za

Address for correspondence: Department of Microbiology, Forestry and Agricultural Biotechnology Institute (FABI), University of Pretoria, Private Bag X20, Hatfield, Pretoria, 0028, South Africa

Tel: +27 12 4203938/9

Fax: +27 124203960

Email: jolanda.roux@fabi.up.ac.za

\begin{abstract}
Chrysoporthe austroafricana (Cryphonectriaceae) is a damaging canker pathogen on Eucalyptus species in Southern Africa. Recent studies have shown that the fungus occurs on native Syzygium species and that it has apparently undergone a host range expansion from these native trees to infect non-native Eucalyptus. The aim of this study was to consider whether $C$. austroafricana and other Cryphonectriaceae might exist as endophytes in native Myrtaceae, providing a source of inoculum to infect non-native Myrtales. Healthy branches were collected from Myrtaceae in
\end{abstract}


Mozambique, incubated in florist foam, allowed to dry gradually and monitored for the appearance of fruiting bodies resembling species in the Cryphonectriaceae. Isolates were identified based on DNA sequence data. Two species in the Cryphonectriaceae were obtained, representing the first evidence that species in the Cryphonectriaceae occur as endophytes on native Myrtales, thus providing a source of inoculum to infect non-native and susceptible trees. This has important implications regarding the movement of planting stock used by ornamental tree and forestry enterprises.

Key words: canker pathogens; forestry; Melastomataceae; Myrtaceae; plants for planting; quarantine

\section{INTRODUCTION}

Fungi in the Cryphonectriaceae include a number of important tree pathogens globally, both in native and commercial plantation ecosystems (Gryzenhout et al. 2009). The best known of these is Cryphonectria parasitica, the cause of chestnut blight, that has lead to the near extinction of American and European chestnut trees in their respective native ranges (Anagnostakis 1987). Related species in the genus Chrysoporthe (previously known as species of Cryphonectria) gained notoriety in the 1970 's when they were identified as important pathogens of commercially grown Eucalyptus species in Brazil (Hodges et al. 1976; Wingfield 2003).

Chrysoporthe (Cryphonectriaceae) includes a number of important eucalypt pathogens (Gryzenhout et al. 2009; Wingfield 2003), including C. austroafricana in 
Africa (Gryzenhout et al. 2004; Nakabonge et al. 2006), C. cubensis in Latin America (Gryzenhout et al. 2004; Hodges et al. 1976) and Africa (Roux and Apetorgbor 2010), and C. deuterocubensis in Asia (Sharma et al. 1985; Van der Merwe et al. 2010) and Africa (Nakabonge et al. 2007). Infections by Chrysoporthe species result in stem and root collar cankers after colonization of the bark, cambium and woody tissues at the bases of Eucalyptus trees (Hodges et al. 1976; Sharma et al. 1985; Wingfield et al 1989). Infection of young trees results in death, while stem cankers on older trees make the stems prone to wind breakage (Nakabonge et al. 2006; Sharma et al. 1985; Wingfield 2003).

Chrysoporthe species have a host range restricted to plants in the family Myrtales. Host genera include Lagerstroemia (Gryzenhout et al. 2006), Miconia (Rodas et al. 2005), Psidium (Hodges 1988), Syzygium (Hodges et al. 1986), Tibouchina (Wingfield et al. 2001) and a number of others (Barreto et al. 2006; Gryzenhout et al. 2006; Seixas et al. 2004). In most countries where Eucalyptus species are grown as non-natives, they occur in close proximity to related, native plants in the Myrtales (Seixas et al. 2004; Wingfield et al. 2001). The occurrence of similar fungal species on both the native and non-native hosts suggests that some Chrysoporthe species have undergone host shifts (Slippers et al. 2005) from the native Myrtales, eg. Miconia, Syzygium, Tibouchina species, to infect non-native Eucalyptus spp. (Heath et al. 2006, Van der Merwe et al. 2010, 2012). Evidence from population genetic studies suggests that $C$. cubensis is native to Latin America (Gryzenhout et al. 2009), where it underwent a host shift from native Myrtales to infect non-native Eucalyptus species (Van der Merwe et al. 2012). Similarly, C. austroafricana is an African fungus that 
has undergone a host shift from native African Myrtales (Heath et al. 2006) to infect Australian Eucalyptus species grown as non-natives in plantations.

At least two of the Eucalyptus pathogens, C. cubensis and C. deuterocubensis have moved beyond their purported regions of origin. Chrysoporthe cubensis, believed to be native in South and Central America, has been found in Central and West Africa (Gibson 1981; Roux et al. 2003; Roux and Apetorgbor 2010). Likewise, $C$. deuterocubensis, which is believed to be native to Asia (Myburg et al. 2002; Pegg et al. 2010; van der Merwe et al. 2010), has been found in East and Southern Africa (Nakabonge et al. 2006; Van der Merwe et al. 2010). These important pathogens have been recorded only from non-native Eucalyptus species and S. aromaticum (clove) in Africa. The limited distribution of $C$. deuterocubensis outside East Africa, together with a low population diversity (Nakabonge et al. 2007), strongly supports the hypothesis that it was introduced to the African continent, most likely from Asia with the trade in cloves (Gryzenhout et al. 2006; Roux et al. 2003).

The accidental movement of fungi to new environments, and the disease epidemics that have subsequently arisen in some cases, has raised increasing concern as the incidence and impact of these introductions has increased (Brasier 2008; DesprezLoustau et al. 2007; Liebhold et al. 2012; Wingfield et al. 2015). The trade in life plants, sometimes also referred to as "plants for planting", and timber have been identified as two of the main pathways of pathogen introductions into new regions (Brasier 2008; Liebhold et al. 2012). It has for example been suggested that the chestnut blight pathogen, C. parasitica, was introduced into the United States of America with living plants (Dutech et al. 2012; Milgroom et al. 1992), while the most 
likely route of movement of Chrysoporthe species is still not well understood. A pathway of spread that has not received attention for fungi in the Cryphonectriaceae, is where they might have been carried as symptomless endophytes. This would be in seemingly healthy plants or commercially traded plant tissue such as that used for floral arrangements.

Endophytes are microorganisms living within plant tissues, for all or part of their life cycle, without causing any apparent or detectable symptoms of disease (Arnold et al. 2003; Bacon and White 2000; Petrini et al. 1993). These organisms can be latent or opportunistic pathogens, causing disease when infected plants are exposed to unsuitable environmental conditions (Bacon and White 2000). Some endophytic microorganisms have also been reported to benefit their host plants by providing protection from herbivores or insect infestation (Arnold and Lewis 2005; Clay 1986; Siegel et al. 1985), by enhancing growth (Ren et al. 2011), improving drought tolerance (Hubbard et al. 2012) and protection against pathogens (Arnold et al. 2003). Endophytes probably occur in all plant species and plant parts (Rosenblueth and Martínez Romero 2006; Sturz et al. 2000) and while they contribute significantly to the hyper-diversity of fungi, they typically go unnoticed (Arnold 2008; Hawksworth 2001).

Despite the fact that Chrysoporthe species are important pathogens of Eucalyptus species, very little is known regarding their origin or how they have emerged as important pathogens on non-native, commercially propagated trees. The fact that $C$. austroafricana is found sporulating on bark and dead branches of native Myrtaceae in areas where the fungus occurs as a pathogen of Eucalyptus suggests that the fungus 
and its relatives possibly could occur as non-damaging endophytes in asymptomatic trees. The aim of this study was to test this hypothesis by making isolations from asymptomatic tissues of Myrtales growing in a native environment and to identify the resulting fungi. Because fungi in the Cryphonectriaceae are likely to develop and sporulate gradually as plant tissue dies, a novel technique to detect possible infections by them was applied.

\section{MATERIALS AND METHODS}

\subsection{Endophyte isolations}

During the course of two field surveys in Mozambique in July 2010 and August 2011, segments $(\sim 30 \mathrm{~cm}$ length, $\sim 1 \mathrm{~cm}$ diameter) were cut from healthy branches of various native and non-native Myrtales in eucalypt-growing areas of the country. All leaves were removed from the samples at the time of collection. Trees sampled included native species of Dissotis and Syzygium, Eugenia capensis, and non-native Psidium guajava in the Central, Northern and Southern Provinces of Mozambique (Table 1). A total of 89 trees, collected in six provinces of Mozambique, were sampled. Six trees were from Inhambane (Syzygium guineense), seven were from Gaza (four of E. capensis and three of Syzygium cordatum), 23 from Nampula (20 S. guineense and three $S$. cordatum), ten from Niassa (six Dissotis sp., two $S$. cordatum and two $S$. guineense), ten from Sofala (one P. guajava, two $S$. cordatum, three $S$. guineense and four Syzygium sp.) and 33 trees from Zambézia (two Dissotis sp., two P. guajava, 13 S. cordatum, 16 S. guineense (Table 1). The numbers and species of trees sampled 
Table 1. Number of Myrtalean trees sampled and number of trees from which endophytic Cryphonectriaceae were obtained in Mozambique

\begin{tabular}{|c|c|c|c|c|}
\hline Host ID & Geographic origin & $\begin{array}{l}\text { Number of trees } \\
\text { sampled per host } \\
\text { species }\end{array}$ & $\begin{array}{l}\text { Number of trees with } \\
\text { Cryphonectriaceae } \\
\text { isolated }\end{array}$ & $\begin{array}{l}\text { Identity of Cryphonectriaceae } \\
\text { species obtained }\end{array}$ \\
\hline Dissotis sp. & Niassa, Lichinga & 6 & 2 & Chrysoporthe austroafricana \\
\hline Eugenia capensis & Gaza, Zongoene & 4 & 0 & \\
\hline Psidium guajava & Sofala, Galinha & 1 & 1 & Chrysoporthe austroafricana \\
\hline \multirow{2}{*}{ Syzygium cordatum } & Nampula, Ilha de Mozambique & 3 & 2 & Chr. austroafricana \\
\hline & Niassa, Lichinga & 2 & 1 & Chr. austroafricana \\
\hline
\end{tabular}


Sofala, Galinha

Zambézia, Gurué

Inhambane, Inhambane

Inhambane, Inharrime

Nampula, Ilha de Mozambique

Nampula, Ribáuè

6

Niassa, Lichinga

Sofala, Galinha

Zambézia, Gurué

Sofala, Galinha
13

3

14

2

2

13

1

6

3

0

5
Chr. austroafricana

Chrysoporthe austroafricana

Chrysoporthe austroafricana

Chrysoporthe austroafricana

Chrysoporthe austroafricana

Chrysoporthe austroafricana

Chrysoporthe austroafricana

Chrysoporthe austroafricana

Chrysoporthe austroafricana 
were dependent on their availability, since in most areas, native trees have been burned and felled for replacement with agricultural crops.

Branch segments were placed in individual brown paper bags, which were sealed in larger plastic bags to retain moisture, and transported to the laboratory. All the branch samples were surface-disinfested with $70 \%$ ethanol for 1 min to remove epiphytes and then placed in moist chambers to induce the growth and sporulation of species in the Cryphonectriaceae from within and below the bark. Moist chambers consisted of moistened florist foam in square plastic containers, or 1.5 liter plastic bottles, moistened with a small quantity of water at the base of the container to prevent the plant material from drying out inordinately rapidly. Branch samples were inserted into the florist foam and the containers were placed in a greenhouse at $25^{\circ} \mathrm{C}$, with natural day-night lighting. The lids were removed from the cake savers and plastic bottles as keeping them on resulted in too much moisture accumulation on the plant material. Branch samples were monitored weekly for the presence of fruiting structures resembling those of the Cryphonectriaceae, and to ensure that a moist environment was maintained. All branch samples were monitored over a two month period.

Where fungal fruiting bodies were present, single spore drops were transferred, using a sterile needle, to 2\% Malt Extract Agar (MEA) including $20 \mathrm{~g} / \mathrm{L}$ of agar (Biolab, Midland, Johannesburg) and $15 \mathrm{~g} / \mathrm{L}$ malt with $100 \mathrm{mg} / \mathrm{L}$ streptomycin sulphate (Sigma-Aldrich Chemie Gmbh, Steinheim, Germany) and incubated at $25{ }^{\circ} \mathrm{C}$ until the onset of fungal growth. For some fungi, fruiting bodies were cut open using a sharp, sterile scalpel blade, and the exposed spore masses transferred to sterile $2 \%$ MEA. Where no fresh spore drops were visible, plant tissue was incubated in moist 
chambers to induce spore production. Pure cultures of all isolates obtained in this study are maintained in the Culture Collection (CMW) of the Forestry and Agricultural Biotechnology Institute (FABI), University of Pretoria, South Africa.

\subsection{Identification of isolates}

Fungi obtained from branch samples were identified based on morphological characteristics and comparisons of DNA sequence data. All putative Cryphonectriaceae isolated from different species of the Myrtales, and from different geographic regions, were selected for identification based on DNA sequencing (Table 1).

\subsubsection{DNA extraction}

For DNA extraction, mycelium was harvested from actively growing cultures of isolates resembling species in the Cryphonectriaceae and placed in $1.5 \mathrm{ml}$ sterile Eppendorf tubes and freeze dried overnight. Mycelium was then ground to a fine powder using sterile metal beads on a Mixer Mill (Type MM 301, Retsch® tissue lyser, Retsch, Germany) for two minutes at 30 cycles per second. DNA was extracted and purified using the Cetyl Trimethyl Ammonium Bromide (CTAB) method as described by Möller et al. (1992). The nucleic acids were then pelleted using centrifugation ( $2800 \mathrm{rpm}$ for two minutes) and washed in $70 \%$ ethanol, followed by suspension in sterilized distilled water. Two microliters of RNaseA $(10 \mu \mathrm{g} / \mu \mathrm{l})$ were added to each tube and incubated at room temperature for 24 hours to digest residual RNA. The concentrations of the extracted DNA samples were determined using a 
Nanodrop ND-1000 Spectrophotometer v.3.6 (Thermo Fisher Scientific, Wilmington, USA).

\subsubsection{PCR amplification and purification}

The polymerase chain reaction (PCR) was used to amplify the internal transcribed spacer (ITS1, ITS2) regions, including the $5.8 \mathrm{~S}$ gene of the ribosomal RNA (rRNA) operon, with the primer pair ITS1 and ITS4 (White et al. 1990) for all isolates. Depending on identities based on the ITS and 5.8S sequence results, sequence data were also obtained for the $\beta$-tubulin 1 and $\beta$-tubulin 2 regions (BT) with primers BT1a/ BT1b, BT2a/ BT2b (Glass and Donaldson 1995). The PCR reaction mixtures used to amplify the different loci consisted of 2.5 units FastStart Taq polymerase (Roche Applied Science, USA), $1 \times$ PCR buffer, $1-1.5 \mathrm{mM} \mathrm{MgCl}_{2}, 0.25 \mathrm{mM}$ of each dNTP, $0.5 \mu \mathrm{m}$ of each primer and approximately $50-100 \mathrm{ng}$ of fungal genomic DNA, made up to a total reaction volume of $25 \mu \mathrm{l}$ with sterile de-ionised water. The amplification conditions included an initial denaturation of the double stranded DNA at $96{ }^{\circ} \mathrm{C}$ for $1 \mathrm{~min}$, followed by 35 cycles of $30 \mathrm{~s}$ at $94{ }^{\circ} \mathrm{C}$, annealing for $1 \mathrm{~min}$ at 54 ${ }^{\circ} \mathrm{C}$ to $56{ }^{\circ} \mathrm{C}$ (depending on the primer), extension for $90 \mathrm{~s}$ at $72{ }^{\circ} \mathrm{C}$ and a final elongation step of $10 \mathrm{~min}$ at $72{ }^{\circ} \mathrm{C}$. The PCR amplification products were separated by electrophoresis on $2 \%$ agarose gels stained with GelRed in a TAE buffer and visualized under UV light. Amplified fragments were purified using Centri-sep mini spin columns (Princeton Separations, Adelphina, HJ) containing 6\% Sephadex G-50 (Sigma, Steinhein, Germany) following the manufacturer's instructions. 


\subsubsection{DNA sequencing and phylogenetic analyses}

The purified PCR products were used as template DNA for cycle sequencing reactions using an Icycler thermal Cycler to generate sequences in both the forward and reverse directions with the same primers used for the PCR reactions, in $10 \mu \mathrm{l}$ PCR mixtures. The composition of the mixture was $2 \mu$ of Sabax water, $2 \mu \mathrm{l}$ ready reaction buffer (BigDye), $1 \mu \mathrm{l}$ of $5 \mathrm{x}$ reaction buffer, $1 \mu \mathrm{l}$ primer $(10 \mathrm{mM})$ and $4 \mu \mathrm{l}$ of the PCR product. The BigDye terminator sequencing kit v3.1 (Applied Biosystems, USA) and an ABI PRISM ${ }^{\mathrm{TM}} 3100$ DNA sequencer (Applied Biosystems, USA) were used for sequencing reactions.

Sequences for isolates obtained in this study were compared against the data base of the National Centre for Biotechnology Information (NCBI, http://www.ncbi.nlm.nih.gov/BLAST/) to obtain an indication of their identities. For all isolates residing in in the Cryphonectriaceae, additional sequences for comparison were obtained from Genbank (http://www.ncbi.nlm.nih.gov) and TreeBASE (http://www.treebase.org) and combined into datasets for further analyses (Table 2). Sequence alignments were made using the online interface (http://align.bmr.kyushuu.ac.jp/mafft/software/) of MAFFT v. 5.667 (Katoh et al. 2002), incorporating the GINS-i alignment algorithm. When sequences were not satisfactorily aligned by MAFFT, alignments were checked and adjusted manually.

PAUP* 4.0 (Swofford 2002) was used to determine the phylogeny of aligned sequences. Sequence data sets for the ITS and BT regions were first analyzed separately, and then in combined analyses. Before combining sequence data sets, a 
Table 2. Sequences obtained in this study and from GenBank.

\begin{tabular}{|c|c|c|c|c|}
\hline Species name & Isolate no. $^{\text {a }}$ & Host & Origin & GenBank accession no. $^{b}$ \\
\hline Celoporthe dispersa & CMW9978 & Syzygium cordatum & South Africa & AY214316, DQ267135, DQ267141 \\
\hline Cel. dispersa & CMW9976 & S. cordatum & South Africa & DQ267130, DQ267136, DQ267142 \\
\hline Cel. eucalypti & CMW26911 & Eucalyptus EC48 clone & China & HQ730838, HQ730818, HQ730828 \\
\hline Cel. eucalypti & CMW26913 & Eucalyptus EC48 clone & China & HQ730839, HQ730819, HQ730829 \\
\hline Cel. guangdongensis & CMW12750 & Eucalyptus sp. & China & HQ730830, HQ730810, HQ730820 \\
\hline Cel. indonesiensis & CMW10779 & S. aromaticum & Indonesia & AY084007, AY84031, AY084007 \\
\hline Cel. indonesiensis & CMW10780 & S. aromaticum & Indonesia & AY084008, AY084032, AY084008 \\
\hline Cel. syzygii & CMW24912 & Syzygium sp. & China & HQ730833, HQ730813, HQ730823 \\
\hline Cel. syzygii & CMW24914 & Syzygium sp. & China & HQ730834, HQ730814, HQ730824 \\
\hline Cel. woodiana & CMW13936 & Tibouchina granulosa & South Africa & DQ267131, DQ267137, DQ267143 \\
\hline Cel. woodiana & CMW13937 & T. granulosa & South Africa & DQ267132, DQ267138, DQ267144 \\
\hline Cel. woodiana ${ }^{c}$ & CMW37246 & S. cordatum & Zongoene, Gaza, Mozambique & JX842758, JX842770, JX842764 \\
\hline Cel.fontana & CMW29375 & S. guineense & Zambia & GU726940, GU726952, \\
\hline
\end{tabular}




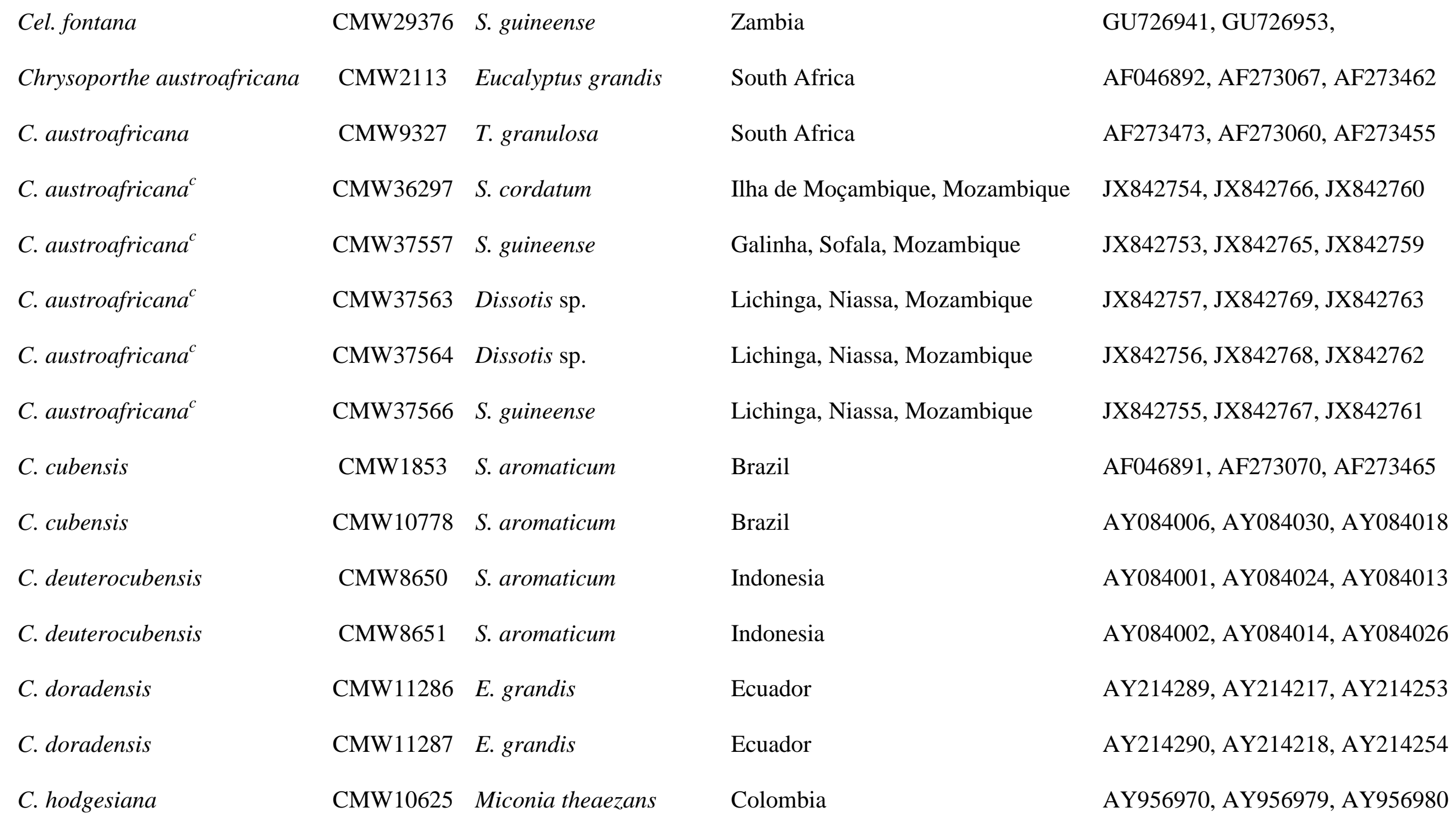




\begin{tabular}{llll} 
C. hodgesiana & CMW10641 & T. semidecandra & Colombia \\
C. inopina & CMW12727 & T. lepidota & Colombia \\
C. inopina & CMW12729 & T. lepidota & Colombia \\
C. syzygiicola & CMW29940 & S. guineense & Zambia \\
C. syzygiicola & CMW29941 & S. guineense & Zambia \\
C. zambiensis & CMW29928 & E. grandis & Zambia \\
C. zambiensis & CMW29929 & E. grandis & Zambia \\
Cryphonectria parasitica & CMW7048 & Quercus virginiana & Japan \\
Cryphonectria parasitica & CMW13749 & Castanea mollisima & Japan \\
\hline
\end{tabular}

AY692322, AY692326, AY692325 DQ368777, DQ368806, DQ368807 DQ368778, DQ368808, DQ368809

FJ655005, FJ805230, FJ805236

FJ655006, FJ805231, FJ805237

FJ655002, FJ858709, FJ805233

FJ655003, FJ858710, FJ805234

AF368330, AF273076, AF273470

AY697927, AY697943, AY697944

${ }^{\mathrm{a}} \mathrm{CMW}$ refers to Culture collection of Forestry and Agricultural Biotechnology Institute (FABI), University of Pretoria, Pretoria, South Africa

${ }^{\mathrm{b}}$ Accession numbers refers to sequence data of the ITS, $\beta$-tubulin 1 and $\beta$-tubulin 2 gene regions

${ }^{\mathrm{c}}$ Isolates obtained in this study 
partition homogeneity test (PHT) (Farris et al. 1994) was conducted to determine whether the data sets could be combined. For the analyses, combined data of rDNA ITS and BT sequences were examined prior to exclusion of uninformative sites, using 1000 replicates, to ascertain whether they could be collectively analyzed. All gaps were coded as missing data and characters were assigned equal weight. Maximum Parsimony (MP) analyses were done in PAUP 4.0 (Swofford 2002). The Heuristic search option with random stepwise addition and tree bisection reconnection (TBR) was used as the swapping algorithm. The Mulpar option was in effect and branches collapsed if they equaled zero. Confidence levels of the branching points were determined using 1000 bootstrap replicates and distribution of 1000 trees.

For phylogenetic analyses, Cryphonectria parasitica, which was defined as a paraphyletic sister group to the in-group taxa, was chosen as the out-group taxon. For the parsimony analyses, the tree length (TL), retention index (RI), consistency index (CI), rescaled consistency index (RC) and homoplasy index (HI) were determined.

\section{RESULTS}

\subsection{Endophyte isolations}

Fungal fruiting bodies resembling species in the Cryphonectriaceae began to appear on branch samples after two months of incubation, and as samples gradually dried in the florist foam. Yellow to orange tinged stromata and ascomatal and pycnidial necks, exuding mostly orange to yellow spore masses, were found breaking through the bark

of branches. Isolations were made directly from these spore masses. Isolates 
resembling species of Cryphonectriaceae were obtained from native Dissotis sp. in Niassa Province, S. cordatum and S. guineense in Inhambane, Gaza, Nampula, Niassa, Sofala and Zambézia Provinces. Isolates of this group of fungi were also obtained from non-native $P$. guajava in the Sofala Province. In total, putative Cryphonectriaceae isolates were obtained from 35 of the 89 branch samples considered in this study.

\subsection{Identification of isolates}

DNA was obtained from all isolates tentatively identified as of the Cryphonectriaceae and sequence products of $\sim 600 \mathrm{bp}$ were obtained for the ITS regions and $\sim 500 \mathrm{bp}$ for the BT regions. Blast searches with these sequences suggested the presence of two genera amongst the isolates. The combined dataset for the ITS and BT gene regions had a total length of 1007 characters. From this dataset, 700 characters were excluded and 307 characters were parsimony-informative. The partition homogeneity test of the combined regions conducted in PAUP resulted in a P-value of 0.01 , thus lower than the conventionally accepted value of 0.05 required to combine data. However, several studies have accepted P-values greater than 0.001 (Cunningham 1997; Dettman et al. 2003) and a decision was made to do so in this case. The parsimony analysis of the combined dataset resulted in the retention of 91 most parsimonious trees $(\mathrm{TL}=316$, $\mathrm{CI}=0.854, \mathrm{RI}=0.968, \mathrm{RC}=0.827, \mathrm{HI}=0.146)$.

Isolates collected in this study grouped with Chrysoporthe austroafricana and Celoporthe woodiana (Figure 1). For Chr. austroafricana, three isolates were 


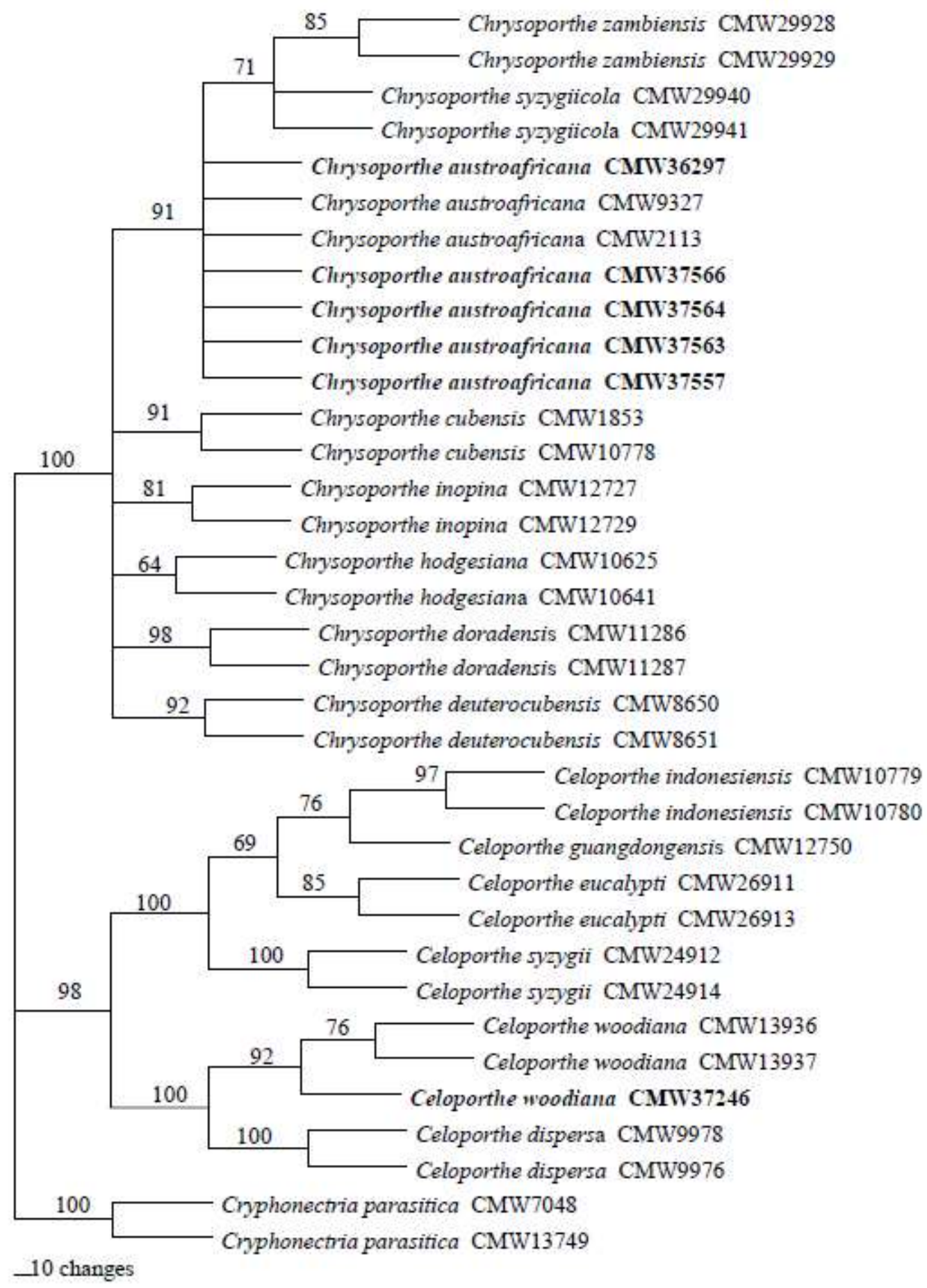

Fig 1. Phylogram of fungi in the Cryphonectriaceae indicating the phylogenetic positions of the fungal pathogen Chr. austroafricana and Cel. woodiana occurring on native Myrtales in Mozambique. Most parsimonious tree obtained from heuristic search of the combined $\beta$ tubulin genes and Internal Transcribed Spacer (ITS) regions of the rDNA sequence data (TL $=316, \mathrm{CI}=0.854, \mathrm{RI}=0.968, \mathrm{RC}=0.827, \mathrm{HI}=0.146)$. Bootstrap confidence levels $(1000$ replicates) are indicated above the internodes. The tree is rooted to the out-group taxa of $C$. parasitica. Isolates obtained in this study are in bold. Only six isolates were chosen for representation in the trees. These were selected to represent each of the hosts and geographic areas from which the endophytic Chryphonectriaceae in this study originated. 
obtained in Niassa Province from Dissotis and S. cordatum; 11 isolates were obtained in Nampula Province, from S. cordatum and S. guineense; 11 isolates were obtained in Zambézia Province, from S. cordatum and S. guineense; five isolates were obtained in Sofala Province, from P. guajava, S. cordatum, S. guineense and one unknown Syzygium sp.; four isolates were obtained in Inhambane Province, from S. guineense. For Cel. woodiana only one isolate was collected and this was from S. cordatum from Xai-Xai in the Gaza Province (Table 1).

\section{DISCUSSION}

The results of this study show conclusively, and for the first time, that members of the Cryphonectriaceae exist as endophytes in host plants. This discovery is important because it provides an explanation for many recent and surprising outbreaks of cankers caused by the Cryphonectriaceae, particularly in South America, Southern Africa and South East Asia (Gryzenhout et al. 2004; Heath et al. 2006; Myburg et al. 2002; Nakabonge et al. 2006; Roux et al. 2005). Where pathogens residing in this group of fungi have emerged as apparently non-native, for example C. cubensis in Africa (Gibson 1981, Myburg et al. 2002, Roux et al. 2003), it now seems likely that the fungus would have been introduced into that area on plant material, such as that of Eucalyptus, used in plantation development, or on ornamental Myrtales brought into the region.

It has previously been speculated that members of the Cryphonectriaceae in Africa might originate from endophytic infections. However, attempts to isolate these fungi as endophytes by Vermeulen et al. (2011) were not successful. This might be 
explained by the fact that isolations on agar could have been overgrown by more rapidly developing fungi such as for example the Botryosphaeriaceae, which are common endophytes in Angiosperm trees including the Myrtales (Pavlic et al. 2007; Roux et al. 2000, 2001; Smith et al. 1996b; Slippers and Wingfield 2007). In addition, endophytic infections are obviously not uniformly found across plant (in this case branch) tissue and isolations from small pieces of tissue could easily not have included the Cryphonectriaceae.

A unique, but simple aspect of this study was the technique used to determine the possible presence of the Cryphonectriaceae in branch samples. Here, we attempted to simulate a slow drying of the branch samples, as might occur on broken branches falling to the understory in forests. The notion to use this approach arose from an observation (Wingfield M.J unpublished) of abundant fruiting structures of the Cryphonectriaceae on branches of Tibouchina species in Colombia, where these trees are commonly infected by various Chrysoporthe species (Gryzenhout et al. 2004; Rodas et al. 2005; Wingfield et al. 2001). Thus, placing branch samples with considerable surface area into moistened florist foam, allowing the samples to dry out slowly over a number of months, stimulated the Cryhonectriaceae present to develop and sporulate. This would also explain previous observations where the Cryphonectriaceae have often be found sporulating on branch stubs and dead bark of native trees (Vermeulen et al. 2011).

Two species of Cryphonectriaceae were discovered as endophytes on Myrtales in this study. Of these, C. austroafricana has previously been reported from Eucalyptus species in Mozambique (Nakabonge et al. 2006; Roux et al. 2005) and is most likely 
native to Africa (Heath et al. 2005, 2006; Nakabonge et al. 2006; Vermeulen et al. 2011). Chrysoporthe austroafricana is also known to occur on Eucalyptus spp. in Malawi, Mozambique, South Africa and Zambia (Nakabonge et al. 2006; Roux et al. 2005), non-native Tibouchina in South Africa (Myburg et al. 2002) and native Syzygium in South Africa (Heath et al. 2006), Zambia (Chungu et al. 2010) and Namibia (Vermeulen et al. 2011).

The discovery of C. austroafricana as a endophyte on native Dissotis, S. cordatum and $S$. guineense in this study provides added evidence that this fungus is native to Africa. It is unlikely that it is a serious pathogen on these native plants but importantly, it is able to move to non-native and commercially important plants such as Eucalyptus, and to cause serious disease problems (Gryzenhout et al. 2009; Old et al. 2003; Pegg et al. 2010; Wingfield et al. 1989, 1997).

The second species of Cryphonectriaceae found in this study was represented by only a single isolate. This was tentatively identified as Cel. woodiana, although there were sufficient sequence differences to suggest that it might represent a unique species. Celoporthe woodiana is a recently described species, which prior to the present study, was known only from the non-native garden-tree Tibouchina granulosa in South Africa (Vermeulen et al. 2011). It has, however, also been shown to infect Syzygium and Eucalyptus species in artificial inoculation studies (Vermeulen et al. 2011). The fact that this fungus was found as an endophyte of a native Syzygium sp. could suggest that it is native to Southern Africa, and like C. austroafricana, could easily emerge as an important pathogen of Eucalyptus species in the region. 
Many species of Myrtales are planted as non-natives globally and they include some of the most important commercially propagated plantation trees as well as popular ornamentals. The discovery that the Cryphonectriaceae, including some of the most important and damaging pathogens of trees (Gryzenhout et al. 2009), exist as endophytes in native trees, suggests strongly that infected plant material, such as rooted or even unrooted cuttings has been, and continues to be, a source of movement of these pathogens. Clearly, the appearance of these fungi as serious pathogens has arisen from native and apparently non-damaging fungi undergoing host shifts to infect non-native and susceptible commercially propagated Eucalyptus species in South and Central America, Africa and Asia.

The nursery/plant trade has been, and continues to, actively move seeds, seedlings and plants of the Myrtales internationally (Ferreira et al. 2008; Old et al. 2003; Paine et al. 2011). Species of Chrysoporthe have already been shown to be capable of host shifts between native and non-native Myrtales (Heath et al. 2006; Van der Merwe et al. 2010, 2012) and it is likely that there are many more examples of this situation. Many "new encounter" diseases, both of economic and ecological importance can thus be expected in future (Wingfield et al. 2010). A greater effort must obviously be made to contain the movement of life plants, eg. "Plants for planting", as has been suggested by numerous tree health specialists globally (eg. Montesclaros Declaration www.iufro.org/science/divisions/division-7/70000/publications/montesclarosdeclaration/).

The cross-border movement of living plants represents one of the most important sources of the introduction of plant pathogens into new regions (Liebhold et al. 2012) 
and there have been recent calls for new strategies to limit this threat (Wingfield et al. 2015). The discovery of two species, in two genera of Cryphonectriaceae, as endophytes represents a significant breakthrough in better understanding the pathways of spread of this important group of fungal tree pathogens. The often cryptic nature of endophytes, especially pathogens, makes them of important quarantine concern, since they can move undetected in plant material.

The discovery of members of the Cryphonectriaceae as endophytes in healthy plant tissue raises intriguing questions beyond those species occurring on the Myrtales in the southern Hemisphere. These fungi reside in two very distinct clades, with the genera Cryphonectria dominant on the Fagales in the northern hemisphere, and Chrysoporthe dominant on the Myrtales in the southern Hemisphere (Gryzenhout et al. 2009). It seems probable that important northern hemisphere tree pathogens such as $C$. parasitica would exist as endophytes on trees in for example Asia where it is native (Milgroom et al. 1992, 1996). Existence in this niche would then provide a very plausible means by which $C$. parasitica moved easily on rooted cuttings of the Fagaceae into Europe and North America in the early 1900's. This is an important hypothesis relating to the global movement of tree pathogens that urgently needs testing. The technique described in this study provides an alternative method to detect slower growing endophytes of trees and specifically to obtain cultures needed for pathology and other related studies.

\section{ACKNOWLEDGMENTS}

This work is based on research supported by the National Research Foundation of South Africa (Grant specific unique reference number UID83924). The grant holders 
acknowledge that opinions, findings and conclusions or recommendations expressed in any publication generated by the NRF supported research are that of the authors and that the NRF accepts no liability whatsoever in this regard. We also thank the members of the Tree Protection Co-operative Programme (TPCP), the THRIP initiative of the Department of Trade and Industry, the DST/NRF Centre of Excellence in Tree Health Biotechnology (CTHB) of the Forestry and Agricultural Biotechnology Institute (FABI), University of Pretoria, South Africa for financial support to undertake this work.

\section{REFERENCES}

Anagnostakis SL, 1987. Chestnut Blight: The classical problem of an introduced pathogen. Mycologia 79: 23-37.

Arnold A. E., Mejia L. C., Kyllo D., Rojas E. I., Maynard Z., Robbins N., Herre E. A. (2003). Fungal endophytes limit pathogen damage in a tropical tree. (2003). Proceedings of the National Academy of Sciences 100: 15649-15654.

Arnold A.E., Lewis L.C. (2005). Ecology and evolution of fungal endophytes, and their roles against insects. In: Insect-Fungal Associations: Ecology and Evolution (eds Vega F. E., Blackwell, M.), pp. 74-96. Oxford University Press, New York.

Arnold A. E. (2008). Endophytic fungi: hidden components of tropical community ecology. In: Tropical Forest Community Ecology (eds Schnitzer R., Carson W.), pp. 254-271. Blackwell Scientific, Hoboken, NJ.

Bacon C. W., White J. F. (2000). Microbial endophytes. Marcel Dekker Inc., New York, N.Y. 
Barreto R. W., Rocha F. B., Ferreira F. A. (2006). First record of natural infection of Marlierea edulis by the eucalyptus canker fungus Chrysoporthe cubensis. Plant Pathology 55: 577.

Brasier CM, 2008. The biosecurity threat to the UK and global environment from international trade in plants. Plant Pathology 57: 792-808.

Chungu D., Gryzenhout M., Muimba-Kankolongo A., Wingfield M. J., Roux J (2010). Taxonomy and pathogenicity of two novel Chrysophorte species from Eucalyptus grandis and Syzygium guineense in Zambia. Mycological Progress 9: 379393.

Clay K. (1986). Grass endophytes. In: Microbiology of the phyllosphere (eds Fokkema N. J., van den Heuvel J.), pp. 188-204. Cambridge Univer-sity Press, Cambridge, United Kingdom.

Cunningham C. W. (1997). Is congruence between data partitions a reliable predictor of phylogenetic accuracy? Empirically testing an iterative procedure for choosing among phylogenetic methods. Systematic Biology 46: 464-478.

Desprez-Loustau ML, Robin C, Bue’e M, Courtecuisse R, Garbaye J, Suffert F, Sache I, Rizzo DM, 2007. The fungal dimension of biological invasions. TRENDS in Ecology and Evolution 22: 472-480.

Dettman J. R., Jacobson D. J., Turner E., Pringle A., Taylor J. T. (2003). Reproductive isolation and phylogenetic divergence in Neurospora: comparing methods of species recognition in a model eukaryote. Evolution 57: 2721-2741.

Dutech C, Barrès B, Bridier J, Robin C, Milgroom MG, Ravigné V, 2012. The chestnut blight fungus world tour: successive introduction events from diverse origins in an invasive plant fungal pathogen. Molecular Ecology 21: 3931-3946. 
Farris J. S, Kallersjo M., Kluge A. G., Bult C. (1994). Testing significance of congruence. Cladistics 10: 315-319.

Ferreira A., Quecine M. C., Lacava P. T., Oda S., Azevedo J. L., Araújo W. L. (2008) Diversity of endophytic bacteria from Eucalyptus species seeds and colonization of seedlings by Pantoea agglomerans. FEMS Microbiology Letters 287: 8-14.

Gibson I. A. S. (1981). A canker disease new to Africa. FAO. Forest Genetic Resources Information 10: 23-24.

Glass N. L., Donaldson G. C. (1995). Development of primer sets designed for use with the PCR to amplify conserved genes from filamentous ascomycetes. Applied and Environmental Microbiology 61: 1323-1330.

Gryzenhout M., Myburg H., Van Der Merwe N. A., Wingfield B. D., Wingfield M. J. (2004). Chrysoporthe, a new genus to accommodate Cryphonectria cubensis. Studies in Mycology 50: 119-142.

Gryzenhout M., Myburg H., Hodges C. S., Wingfield B. D., Wingfield M. J. (2006). Microthia, Holocryphia and Ursicollum, three new genera on Eucalyptus and Coccoloba for fungi previously known as Cryphonectria. Studies in Mycology 55: 3552.

Gryzenhout M., Wingfield B. D., Wingfield M. J. (2009). Taxonomy, phylogeny, and ecology of bark inhabiting and tree-pathogenic fungi in the Cryphonectriaceae. The American Phytopathological Society. USA. 119 pp.

Hawksworth D. L. (2001). The magnitude of fungal diversity: the 1.5 million species estimated revisited. Mycological Research 105: 1422-1432.

Heath R. N. (2005). Studies to consider the possible origins of three canker pathogens of Eucalyptus in South Africa. M.Sc. thesis. Department of Plant Pathology, University of Pretoria, South Africa. 
Heath R. N., Gryzenhout M., Roux J., Wingfield M. J. (2006). Discovery of the Cryphonectria canker pathogen on native Syzygium species in South Africa. Plant Disease 90: 433-438.

Hodges C. S., Reis M. S., Ferreira F: A., Henfling J. D. M. (1976). O cancro do eucalipto causado por Diaporthe cubensis. Fitopatologia Brasileira 1: 129-170.

Hodges C. S., Alfenas A. C., Ferreira F. A. (1986). The conspecificity of Cryphonectria cubensis and Endothia eugenia. Mycologia 78: 343-350.

Hodges C. S. (1988). Preliminary exploration for potential biological control agents for Psidium cattleianum. Technical Report 66. Cooperative National Park Resources Studies Unit, Department of Botany, University of Hawaii, Honolulu.

Katoh K., Misawa K., Kuma K., Miyata T. (2002). MAFFT: a novel method for rapid multiple sequence alignment based on fast Fourier transform. Nucleic Acids Research 30: $3059-3066$.

Liebhold A. M., Brockerhoff E. G., Garrett L. J., Parke J. L., Britton K.O. (2012). Live plant imports: the major pathway for forest insect and pathogen invasions of the US. Frontiers in Ecology and the Environment 10: 135-143.

Milgroom M. G., Lipari S. E., Wang K. (1992). Comparison of genetic diversity in the chestnut blight fungus, Cryphonectria (Endothia) parasitica from China and the US. Mycological Research 96: 1114-1120.

Milgroom M. G., Wang K., Zhou Y., Kaneko S. (1996). Intercontinental population structure of the chestnut blight fungus, Cryphonectria parasitica. Mycologia 88: 179190.

Möller E. M., Bahnweg G., Sandermann H., Geiger H. H. (1992). A simple and efficient protocol for isolation of high molecular weight DNA from filamentous fungi, fruit bodies and infected plant tissues. Nucleic Acids Research 20: 6115-6116. 
Myburg H., Gryzenhout M., Heath R., Roux J., Wingfield B. D., Wingfield M. J. (2002). Cryphonectria canker on Tibouchina in South Africa. Mycological Research 106: $1299-1306$.

Nakabonge G., Roux J., Gryzenhout M., Wingfield M. J. (2006). Distribution of Chrysoporthe canker pathogens on Eucalyptus and Syzygium spp. in eastern and southern Africa. Plant Disease 90: 734-740.

Nakabonge G., Roux J., Gryzenhout M., Wingfield B. D., Wingfield M. J., (2007). Genetic diversity of Chrysoporthe cubensis in eastern and southern Africa. South African Journal of Science 103: 1-3.

Old K. M., Wingfield M. J., Yuan Z. Q. (2003). A manual of disease of Eucalypts in South-east Asia. Center for International Forestry Research. Australia. 98 pp.

Paine T. D., Steinbauer M. J., Lawson S. A. (2011). Native and Exotic Pests of Eucalyptus: A Worldwide Perspective. Annual Review of Entomology 56: 181-201.

Pavlic D., Slippers B., Coutinho T. A., Wingfield M. J. (2007). Botryosphaeriaceae occurring on native Syzygium cordatum in South Africa and their potential threat to Eucalyptus. Plant Pathology 56: 624-636.

Pegg G. S., Gryzenhout M., O`Dwyer C., Drenth A., Wingfield M. J. (2010). The Eucalyptus canker pathogen Chrysoporthe cubensis discovered in eastern Australia. Australasian Plant Pathology 39: 1-7.

Petrini O., Sieber T. N., Toti L., Viret O. (1993). Ecology, metabolite production, and substrate utilization in endophytic fungi. Natural Toxins 1: 185-196.

Ren A., Li C., Gao Y. (2011). Endophytic fungus improves growth and metal uptake of Lolium arundinaceum Darbyshire Ex. Schreb. International Journal of Phytoremediation 13: 233-243. 
Rodas C. A., Gryzenhout M., Myburg H., Wingfield B. D., Wingfield M. J. (2005).

Discovery of the Eucalyptus canker pathogen Chrysoporthe cubensis on native Miconia (Melastomataceae) in Colombia. Plant Pathology 54: 460-470.

Rosenblueth M., Martínez-Romero E. (2006). Bacterial endophytes and their interactions with hosts. Molecular Plant-Microbe Interaction 19: 827-837.

Roux J., Coutinho T. A., Wingfield M. J., Bouillet J-P. (2000). Diseases of plantation Eucalyptus in the Republic of Congo. South African Journal of Science 96: 454-456.

Roux J., Coutinho T. A., Mujuni Byabashaija D., Wingfield M. J. (2001). Diseases of plantation Eucalyptus in Uganda. South African Journal of Science 97: 16-18.

Roux J., Myburg H., Wingfield B. D., Wingfield M. J. (2003). Biological and phylogenetic analyses suggest that two Cryphonectria spp. cause cankers on Eucalyptus in Africa. Plant Disease 87: 1329-1332.

Roux J., Meke G., Kanyi B., Mwangi L., Mbaga A., Hunter G. C., Nakabonge G., Heath R. N., Wingfield M. J. (2005). Disease of plantation forestry trees in eastern and southern Africa. Southern Africa Journal of Science 101: 409-413.

Roux J., Apetorgbor M. (2010). First report of Chrysoporthe cubensis from Eucalyptus in Ghana. Plant Pathology 59: 806.

Seixas C. D. S., Barreto R. W., Alfenas A. C., Ferreira F. A. (2004). Cryphonectria cubensis on an indigenous host in Brazil: a possible origin for eucalyptus canker disease? Mycologia 18: 39-45.

Sharma J. K., Mohanan C., Florence E. J. M. (1985). Occurrence of Cryphonectria canker disease of Eucalyptus in Kerala, India. Annuals of Applied Biology 106: 265276.

Siegel M. R., Latch, G. C. M. (1985). Acremonium fungal endophytes of tall fescue and perennial ryegrass: Significance and control. Plant Disease 69: 179-183. 
Slippers B, Stenlid J, Wingfield MJ, 2005. Emerging pathogens: fungal host jumps following anthropogenic introduction. TRENDS in Ecology and Evolution 20: 420421.

Slippers B., Wingfield M. J. (2007). Botryosphaeriaceae as endophytes and latent pathogens of woody plants: diversity, ecology and impact. Fungal Biology Reviews 21: 90-106.

Smith H., Wingfield M. J., Petrini O. (1996a). Botryosphaeria dothidea endophytic in Eucalyptus grandis and Eucalyptus nitens in South Africa. Forest Ecology and Management 89: 189-195.

Smith H., Wingield M. J., Crous P. W., Coutinho T. A. (1996b). Sphaeropsis sapinea and Botryosphaeria dothidea endophytic in Pinus spp. and Eucalyptus spp. in South Africa. South African Journal of Botany 62: 86-88.

Sturz A. V., Christie B. R., Nowak J. (2000). Bacterial endophytes: Potential role in developing sustainable systems of crop production. Critical Reviews in Plant Science 19: $1-30$.

Swofford D. L. (2002). PAUP*. Phylogenetic Analysis Using Parsimony (*and Other Methods). Sinauer Associates, Sunderland, Massachusetts.

Van der Merwe N. A., Gryzenhout M., Steenkamp E. T., Wingfield B. D., Wingfield M. J. (2010). Multiple phylogenetic and population differentiation data confirm the existence of a cryptic species within Chrysoporthe cubensis. Fungal Biology 114: 966-979.

Van der Merwe N. A., Steenkamp E. T., Rodas C., Wingfield B. D., Wingfield M. J. (2012). Host switching between native and non-native trees in a population of the canker pathogen Chrysoporthe cubensis from Colombia. Plant Pathology 62 : 642648. 
Vermeulen M., Gryzenhout M., Wingfield M. J., Roux J. (2011). New records of the Cryphonectriaceae from southern Africa including Latruncellus aurorae gen. sp. nov. Mycologia 103: 554-569.

White T. J., Bruns T., Lee S., Taylor J. (1990). Amplification and direct sequencing of fungal ribosomal RNA genes for phylogenetics. In: PCR protocols: a guide to methods and applications (eds Innis M. A., Gelfand D. H., Sninsky J. J., White T. J.), pp. 315-322. San Diego, Academic Press.

Wingfield M. J., Swart W. J, Abear B. J. (1989) First record of Cryphonectria canker of Eucalyptus in South Africa. Phytophylactica 21: 311-313.

Wingfield M. J., Van Zyl L. M., Van Heerden S., Myburg H., Wingfield B. D. (1997). Virulence and the genetic composition of the Cryphonectria cubensis Bruner population in South Africa. In: Physiology and Genetics of Tree-Phytophage Interactions (eds Lieutier F., Mattson W. J., Wagner M. R.), pp. 163-172. INRA Editions.

Wingfield M. J., Rodas C., Wright J., Myburg H., Venter M., Wingfield B. D. (2001). First report of Cryphonectria canker on Tibouchina in Colombia. Forest Pathology 31: 297-306.

Wingfield M. J. (2003). Increasing threat of diseases to exotic plantation forests in the Southern Hemisphere: lessons from Cryphonectria canker. Australasian Plant Pathology 32: 133-139.

Wingfield M. J., Slippers B., Wingfield B. D. (2010). Novel associations between pathogens, insects and tree species threaten world forests. New Zealand Journal of Forestry Science 40: suppl: S95-S103.

Wingfield, M. J., Brockerhoff E. G., Wingfield, B. D., Slippers. B. (2015). Planted forest health: The need for a global strategy. Science 349: 832-836. 